\title{
Research Use in Education: An Online Survey of School Practitioners
}

\author{
Larysa V. Lysenko \\ Concordia University
}

\section{Philip C. Abrami \\ Concordia University}

Robert M. Bernard
Concordia University

Christian Dagenais

Université de Montréal

\begin{abstract}
This paper summarizes the results of a pan-Canadian online survey study that investigates the extent to which school practitioners $(N=1,153)$ use research to inform their practice. The self-reports indicate that the majority of the respondents used educational research, yet this engagement was infrequent. Although the respondents shared neutral attitudes about research, their comments add rather a negative connotation to their perceptions. This study's findings are relevant to school leadership organizations, teacher education institutions, and research-generating bodies as they point to the necessity of increasing research relevance and accessibility, cultivating teaching as a research-based profession, and building school capacity to use research.
\end{abstract}

Keywords: online survey, self-reported attitudes and behaviours, use of research-based information, factors, school practice

Larysa Lysenko, Ph.D. is a professional researcher at the Centre for the Study of Learning and Performance, Department of Education, Concordia University, 1211 St. Mathieu, Montreal, Quebec, Canada, H3H 2S2

E-mail: larysa.lysenko@education.concordia.ca

Philip C. Abrami, Ph.D. is a Professor, University Research Chair, and the Director of the Centre for the Study of Learning and Performance, Department of Education, Concordia University, 1211 St. Mathieu, Montreal, Quebec, Canada, H3H 2S2

E-mail: abrami@education.concordia.ca

Robert M. Bernard, Ph.D. is Professor of Education and Leader of the Systematic Review Sub-Theme at the Centre for the Study of Learning and Performance, Concordia University, S-FG 6207 Faubourg Ste-Catherine Building, 1610 St. Catherine W., Montreal, Quebec, Canada, H3H 2S2

E-mail: bernard@education.concordia.ca

Christian Dagenais, Ph.D. is Associate Professor of Psychology at the University of Montreal, Pavillon Marie-Victorin, 90 Vincent d'Indy avenue, Montreal, Quebec, Canada, H3C 3J7

E-mail: christian.dagenais@umontreal.ca 


\section{Introduction}

In the past decades, research on educational issues and practices has generated a rich knowledge base that could be used to improve classroom teaching. However, there has been a persistent lack of a systematic application of the research knowledge to teaching practice (e.g., Organization of Economic Co-operation and Development publications, 2007; 2010). While early studies focused on the use of educational research by practitioners, there has been a recent and noticeable shift towards examining research use as a system property, meaning a coordinated series of actions by organizations to produce, transform, and implement research knowledge to improve both teaching practice and learning outcomes. To emphasize the systemic nature of research knowledge utilization and the multiplicity of agents involved, Sharples (2013) introduced the term "knowledge mobilization ecosystem," in which the process of transforming research evidence into actionable knowledge for use is the critical component of the system.

However, this focus on creating and supporting an effective knowledge mobilization system has overshadowed efforts to examine and improve knowledge use by individual practitioners. For instance, Levin (2013) argues: "It is unreasonable and even undesirable to expect individual teachers or principals to be the key consumers of research findings" (p.18). Despite all the importance accorded to research use as an organizational process, it should not be forgotten that the individual teacher remains an agent of change whose actions makes the difference in the classroom.

\section{Conceptual Framework}

The literature suggests that research use is an interpretative process and is affected by more than research information alone. Walter, Nutley, and Davies (2005) suggest that individual characteristics including perceptions, experiences, skills, and social contexts such as organizational settings and broader environments also shape the ways research knowledge trickles down to individual practice. Coburn, Honig, and Stein (2009) specify that "individuals and groups make meaning of evidence in ways that are profoundly shaped by their pre-existing beliefs and practices and day-to-day limits" (p. 86).

Elsewhere Dagenais et al. (2012) have reviewed the empirical evidence regarding potential factors affecting practitioners' use of research evidence. They view research use as a multidimensional construct and draw on the distinction that literature makes between instrumental, conceptual, and symbolic uses. Instrumental use is concerned with the change to concrete practices where research findings are transmitted and applied intact (e.g., Knott \& Wildavsky, 1980). Conceptual (Neilson, 2001) or "enlightenment" use (Weiss, 1980) represents a change in understanding or thinking about an issue that affect practice indirectly. Symbolic or strategic use (e.g., Hughes, McNeish, Newman, Roberts, \& Sachdev, 2000) relates to using research findings to influence decisions, justify actions, or support a decision that has already been made. Estabrooks (1999) calls for this persuasive use, emphasizing that such use can serve the constructive purpose of legitimizing a position or practice. Although research use may occur for one specific purpose or simultaneously for different ends, conceptual use is argued to prevail over and precede the other two (e.g., Sunesson \& Nilsson, 1988).

Relying on the Roger's innovation diffusion framework (2003), Dagenais et al. (2012) group the potential factors influencing practitioner use of research knowledge. At the individual 
level, they identify (1) qualities of research findings as perceived by the practitioner (opinions) and (2) the practitioner's capacity to use this information for a variety of ends (expertise). At the school level, the factors include (3) the school context and culture (organizational factors) that impact practitioners' openness for learning and engagement with research generated in academia or locally in school-based projects. Finally, the authors identify (4) communication and interaction between the levels of the system and its actors (awareness activities) as a factor affecting visibility and consequently practical utility of research findings. The researchers argue that the power of these four factors to determine and predict practitioners' engagement with research must be taken into account in future studies. In fact, a recent empirical study of research use found that school practitioners' attitudes toward research, and their capacity to engage with it, had the most predictive power on the low and infrequent self-reported use of research (Lysenko, Abrami, Bernard, Dagenais \& Janosz, 2014). This paper, which takes educational practitioners as its focus, offers an update on their practitioners' propensity to inform classroom practice with the findings from educational research through the school practitioners' self-reported attitudes and behaviours, gathered by an online, pan-Canadian survey.

\section{Method}

This study is an extension of an earlier project (Lysenko et al., 2014), which was conducted in the narrower context of secondary schools located in disadvantaged areas in a province of Eastern Canada. For this study, the context was broadened to include respondents across Canada teaching in both elementary and secondary schools. The data collection also included the self-reports to open-ended survey questions that were added to the original instrument. While the primary purpose of the study was the validation of the instrument in a broader context, this paper reports the substantive findings with a focus on the qualitative data provided by practitioners.

\section{Instrument}

Data collection was done through the "Questionnaire about the Use of Research-based Information" (QURBI), (Dagenais, Janosz, Abrami, Bernard, \& Lysenko, 2008; Lysenko et al., 2014), originally developed to assess factors that affect the extent of research use by educational practitioners. Figure 1 represents the iterative development and refinement of this instrument including pilot testing and large-scale validation. 


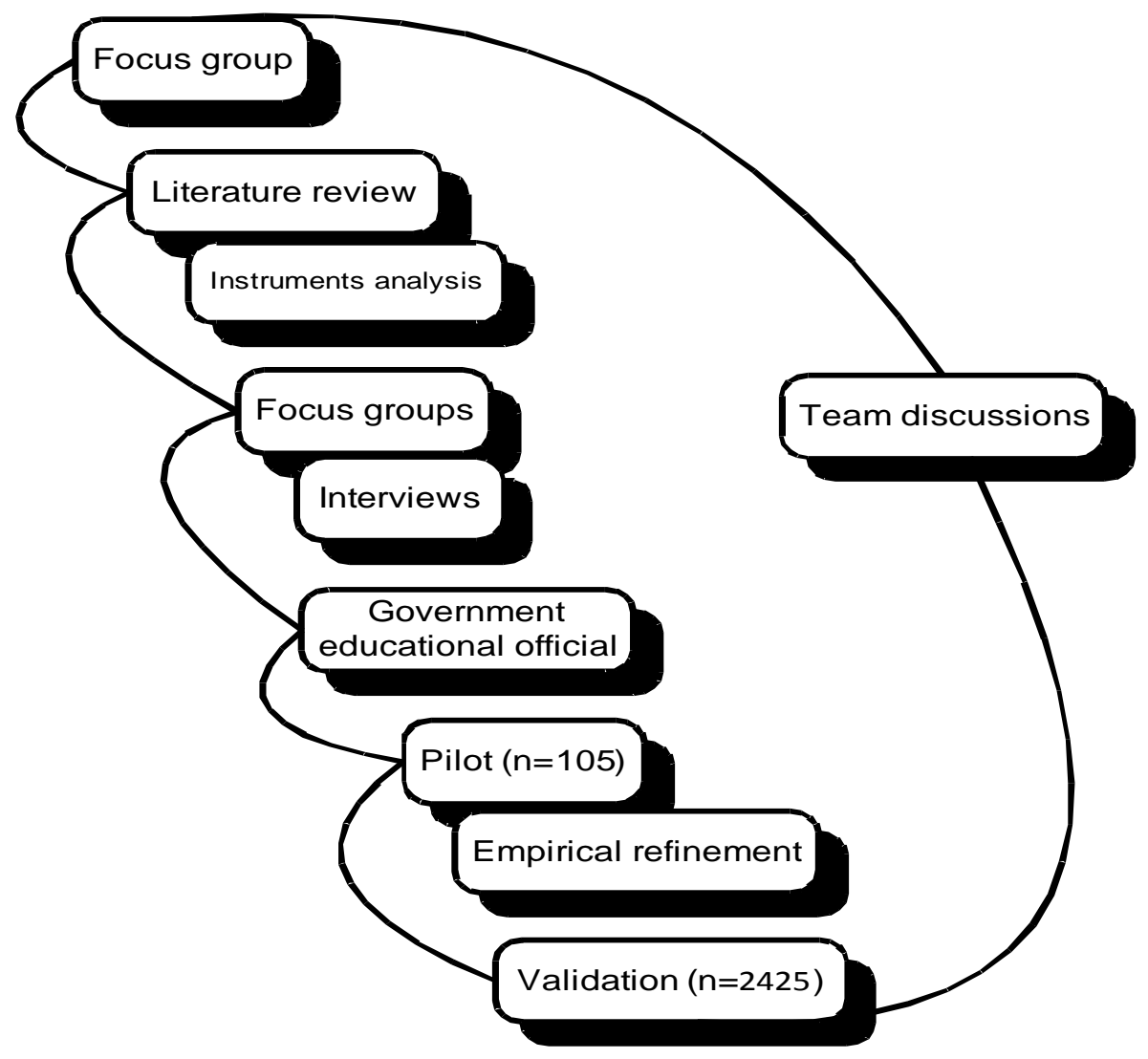

Figure 1. Stages of QURBI development.

The questionnaire was validated with 2,425 secondary school teachers. It demonstrated high internal consistency of 0.92 . The obtained four-factor structure reflected the conceptual framework and accounted for $17 \%$ of the variance in self-reported research use, as well as $22 \%$ of three dimensions of use.

The instrument consists of 43 close-ended items. The first set of outcome variables asked about the use of various sources of research-based information (RBI) which was defined as a free-circulating commodity produced by professional researchers such as research teams from universities, external evaluation teams, or by practitioners conducting research in collaboration with researchers produced locally and intended for local use. Specifically, practitioners were asked to report on how frequently in the past year they used research-based information from different sources, such as scholarly documents, professional publications, and websites. The second set of outcome variables examined the dimensions of the use of research-based information in the past year. Instrumental use was captured through items, such as "to improve professional practice" and "to develop new activities, programs." Conceptual use was measured by the following items: "to achieve a better understanding of practical issues" and "to reflect on one's attitudes and practices." Symbolic use was examined through items related to confirming practices or actions. 
The factor variables (26 items) were provisionally organized into four sections:

1. Opinions about research - focused on the relevance, timeliness, and reliability of research-based information, as well as its usefulness, ease of access and understanding, and transferability to practice.

2. Individual expertise - examined the importance practitioners attached to the skills needed to access, appraise, and translate RBI to their practice.

3. Awareness activities - referred to practitioners' involvement in research, contact with researchers and knowledge brokers, as well as the way research findings are presented to practitioners.

4. Organizational factors - focused on school culture (supportive environment, the importance of professional development, opportunities to challenge habits and traditions), available resources (qualified staff, facilities and technology, time, incentives), and external influences on individual practices (organized groups, such as unions and granting agencies).

Each section of the questionnaire was followed by an open-ended question to elicit practitioners' comments. Additionally, the participants were encouraged to provide demographic data including gender, teaching experience, education level, occupation category, and grade level. School information including geographical location, size, and language of teaching was also gathered. Finally, the survey elicited reports of previous engagement in research such as coursework in research methods or participation in research projects.

\section{Survey Distribution}

The English and French versions of the survey were hosted and distributed through the Canadian Council on Learning's online assessment platform. Provincial and federal teachers' unions were contacted to solicit practitioners to respond to the survey. Non-profit educational organizations and provincial teacher colleges were also asked for assistance. While the recruiting strategies were left to the discretion of these organizations, the majority contacted members electronically -for example, through electronic newsletters, e-mails, and websites.

\section{Analyses}

Standard SPSS procedures were applied to screen data from the 1,611 surveys registered in the online assessment system. After deleting the cases where $60 \%$ or more responses were missing, the remaining surveys had missing data imputed by expectation maximization. No univariate outliers were detected. All multivariate outliers were removed, leaving 1,153 cases for analyses that were completed using SPSS for Windows. To compensate for the unbalanced sample, the mean scores were weighted. Answers to open-ended questions were analysed using NVivo 8. Categories of notions with similar meaning and connotations were developed, relying on both $a$ priori and a posteriori approaches (Leech \& Onwuegbuzie, 2011). A Chi-square test of independence was performed for a potential association between the count of categories emerging from practitioners' comments and the frequency with which they used research-based information. 


\section{Results}

\section{Respondents}

Teachers were the largest category of respondents $(82.1 \%)$ whereas school administrators and professional staff represented $8.7 \%$ each. Teachers had on average 12 years of teaching experience. Most of the teachers (74\%) and professionals (60\%) held an undergraduate degree while $54.4 \%$ of the administrators had a master's degree. Only $1.3 \%$ of respondents had a pre-university education, an undergraduate certificate, or a doctorate degree. In terms of training and involvement in research, 56.3\% of respondents reported having taken some coursework in research methods and $57.8 \%$ of them indicated they had participated in a research project of some kind. Only 29.3\% reported having taken part in school-based research projects. Additionally, the majority of respondents (96.3\%) reported being part of the public school system with 33\% working in secondary and $77 \%$ in primary schools. Only 3.9\% reported French as their working language. Forty-six percent of respondents worked in medium size schools (150-500 students). Almost 90\% of them worked in schools located in suburban and rural areas.

As Table 1 shows, the respondents were distributed across the provinces and territories. It was Ontario practitioners who accounted for $50 \%$ of respondents, with the rest distributed across the provinces and territories.

Table 1

Distribution of Respondents by Province and Category of Employment

\begin{tabular}{|c|c|c|c|c|c|}
\hline & Teachers & Administrators & Professionals & Unknown & Total \\
\hline Alberta & 35 & 17 & 4 & - & 56 \\
\hline British Columbia & 131 & 1 & 10 & - & 142 \\
\hline Manitoba & 12 & 6 & 1 & - & 19 \\
\hline New Brunswick & 142 & 19 & 13 & - & 174 \\
\hline Newfoundland and Labrador & 4 & 8 & - & - & 12 \\
\hline Northwest Territories & - & - & 1 & - & 1 \\
\hline Nova Scotia & 16 & 2 & - & - & 18 \\
\hline Nunavut & - & 2 & - & - & 2 \\
\hline Ontario & 521 & 31 & 51 & - & 603 \\
\hline Prince Edward Island & 5 & 0 & 2 & - & 7 \\
\hline Quebec & 43 & 5 & 17 & - & 65 \\
\hline Saskatchewan & 7 & 5 & 1 & - & 13 \\
\hline Yukon & 1 & 1 & - & - & 2 \\
\hline Unknown & 30 & 4 & 1 & 4 & 39 \\
\hline Total & 947 & 101 & 101 & 4 & 1,153 \\
\hline
\end{tabular}




\section{QURBI Close-ended Questions}

The psychometric statistics obtained in this study corroborated the earlier findings of the survey (Lysenko et al., 2014). Internal consistency reliability coefficients (Cronbach's alpha) were acceptable ranging from 0.77 to 0.92 on the sub-scales and 0.94 on the overall questionnaire. Reflecting the conceptual structure provisionally imposed on the questionnaire, the four-factor solution accounted for $61 \%$ of variance whereas each factor explained from $39 \%$ to $4.6 \%$.

Survey responses show that each source of research-based information (RBI) was used at least once in the past year (Figure 2). The majority of respondents $(85 \%)$ obtained research-based information from resource personnel, whereas only $58 \%$ referred to pre-service training to inform their practice.

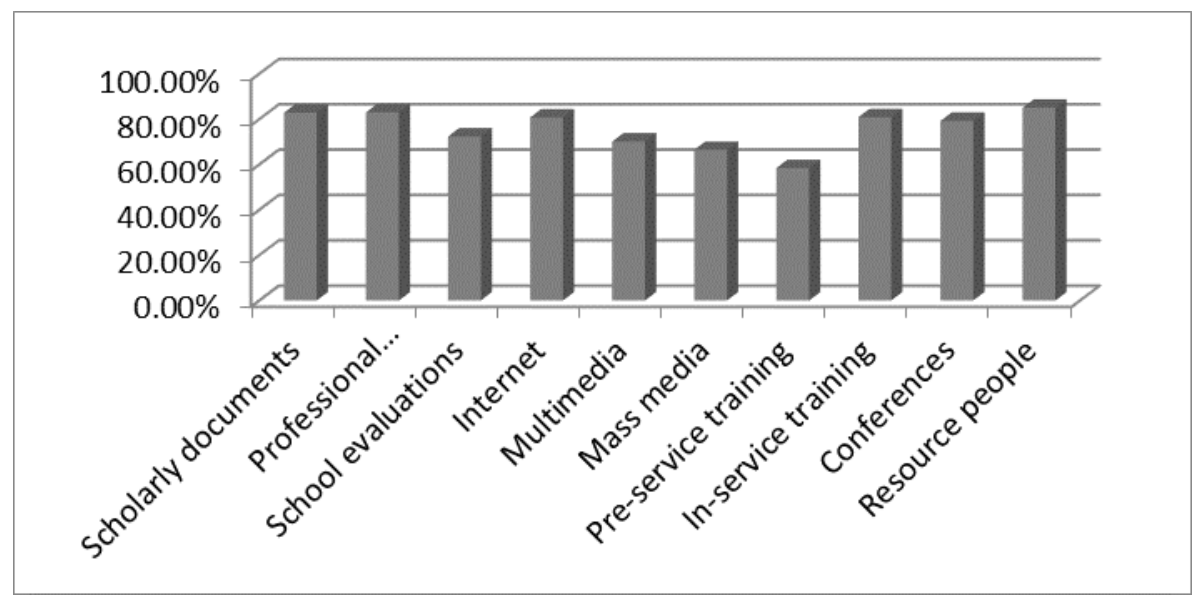

Figure 2. Percent of respondents who used RBI at least once for the past year.

The mean scores summarized in Table 2 reveal that respondents were not particularly avid users of sources that would potentially contain research evidence. Respondents reported having used research-based information on average "once or twice during the past year." However, some amount of variation is noticeable in the reports from all ten sources. Respondents reported using online sources (e.g., websites) most frequently whereas pre-service training was rated as the least used. Interestingly, school evaluations were rated the lowest third. 
Table 2

QURBI Weighted Means and Standard Deviations

\begin{tabular}{|l|c|}
\hline $\begin{array}{l}\text { 1. Rate the frequency with which } \\
\text { you have used the RBI from the } \\
\text { following sources during the last } \\
\text { year: } 0 \text { - never; 3 - five or more } \\
\text { times }\end{array}$ & Means (SD) \\
\hline Scholarly documents & \\
\hline Professional publications & $1.58(1.08)$ \\
\hline School evaluations & $1.53(1.02)$ \\
\hline Internet, web-sites & $1.12(0.99)$ \\
\hline Multimedia: video, DVD & $1.61(1.13)$ \\
\hline $\begin{array}{l}\text { Mass media: TV, radio, } \\
\text { newspapers }\end{array}$ & $1.13(1.02)$ \\
\hline Pre-service training & $1.09(1.04)$ \\
\hline In-service training, workshops & $0.95(1.01)$ \\
\hline $\begin{array}{l}\text { Professional conferences, } \\
\text { presentations }\end{array}$ & $1.41(0.99)$ \\
\hline Experts, resource people & $1.26(0.91)$ \\
\hline Use of RBI composite & $1.43(0.95)$ \\
\hline
\end{tabular}

2. Rate the frequency with which you have used RBI during the last year... 0 -never; 3 -always

\begin{tabular}{|l|l|}
\hline $\begin{array}{l}\text { To achieve a better } \\
\text { understanding of issues in your } \\
\text { practice }\end{array}$ & $1.53(0.77)$ \\
\hline To satisfy intellectual curiosity & $1.60(0.75)$ \\
\hline To improve professional practice & $1.66(0.75)$ \\
\hline $\begin{array}{l}\text { To reflect on your attitudes and } \\
\text { practices }\end{array}$ & $1.47(0.76)$ \\
\hline $\begin{array}{l}\text { To justify or validate your } \\
\text { decisions }\end{array}$ & $1.39(0.77)$ \\
\hline $\begin{array}{l}\text { To resolve problems in your } \\
\text { daily practice }\end{array}$ & $1.22(0.73)$ \\
\hline $\begin{array}{l}\text { To develop new activities, } \\
\text { programs, guidelines }\end{array}$ & $1.57(0.74)$ \\
\hline Conceptual use composite & $1.53(0.67)$ \\
\hline Instrumental use composite & $1.48(0.63)$ \\
\hline Symbolic use & $1.39(0.77)$ \\
\hline
\end{tabular}


3. Rate the extent to which you agree on $R B I \ldots$

1 - strongly disagree, 3 - neutral, 5 - strongly agree

\begin{tabular}{|l|c|}
\hline Is easy to find & $3.12(0.93)$ \\
\hline Is easy to understand & $3.05(0.87)$ \\
\hline Is relevant to your reality & $3.39(0.98)$ \\
\hline Offers timely information & $3.15(0.91)$ \\
\hline Is reliable and trustworthy & $3.29(0.82)$ \\
\hline $\begin{array}{l}\text { Is useful to guide or improve } \\
\text { your professional practice }\end{array}$ & $3.49(0.96)$ \\
\hline $\begin{array}{l}\text { Is easy to transfer into your } \\
\text { practice }\end{array}$ & $3.08(0.95)$ \\
\hline
\end{tabular}

4. Rate the extent to which you agree that the following activities are useful to make you aware of RBI... 1 -strongly disagree, 3 - neutral, 5 - strongly agree

\begin{tabular}{|l|c|}
\hline $\begin{array}{l}\text { Presentation of research findings } \\
\text { tailored to your needs }\end{array}$ & $3.43(0.94)$ \\
\hline $\begin{array}{l}\text { Your involvement in a research } \\
\text { project }\end{array}$ & $3.54(0.95)$ \\
\hline $\begin{array}{l}\text { Research results accompanied by } \\
\text { clear and explicit } \\
\text { recommendations }\end{array}$ & $3.82(0.87)$ \\
\hline $\begin{array}{l}\text { Opportunities to discuss research } \\
\text { results with the research team }\end{array}$ & $3.83(0.84)$ \\
\hline $\begin{array}{l}\text { Regular contacts with people } \\
\text { who distribute research-based } \\
\text { information }\end{array}$ & $3.53(0.93)$ \\
\hline $\begin{array}{l}\text { Demonstrations about how to } \\
\text { apply research recommendations }\end{array}$ & $3.78(0.91)$ \\
\hline $\begin{array}{l}\text { Discussions of research-based } \\
\text { information with colleagues }\end{array}$ & $3.56(0.91)$ \\
\hline $\begin{array}{l}\text { 5. Rate the extent to which you agree that the following skills are necessary in everyday } \\
\text { practice } \ldots \text { l }- \text { strongly disagree, } 3-\text { neutral, 5 - strongly agree }\end{array}$ \\
\hline $\begin{array}{l}\text { Ability to read and understand } \\
\text { research publications }\end{array}$ & $3.91(0.86)$ \\
\hline $\begin{array}{l}\text { Skills to use IT, such as Internet } \\
\text { and databases }\end{array}$ & 4.23(0.79) \\
\hline $\begin{array}{l}\text { Ability to assess the quality of } \\
\text { research-based information }\end{array}$ & $3.82(0.89)$ \\
\hline $\begin{array}{l}\text { Expertise to translate research } \\
\text { findings to practice }\end{array}$ & $3.80(0.92)$ \\
\hline
\end{tabular}




\begin{tabular}{|c|c|}
\hline \multicolumn{2}{|c|}{$\begin{array}{l}\text { 6. Rate the extent to which you agree that the following organizational factors influence use of } \\
\text { RBI...1-strongly disagree, } 3 \text {-neutral, } 5 \text {-strongly agree }\end{array}$} \\
\hline $\begin{array}{l}\text { Available time to read a journal, } \\
\text { apply a new technique, etc. }\end{array}$ & $4.20(0.83)$ \\
\hline $\begin{array}{l}\text { Available facilities and } \\
\text { technology }\end{array}$ & $3.90(0.89)$ \\
\hline $\begin{array}{l}\text { Incentives, such as remuneration, } \\
\text { honoraria, and lessening the } \\
\text { workload }\end{array}$ & $3.31(1.13)$ \\
\hline $\begin{array}{l}\text { Opportunities to challenge } \\
\text { established habits and traditions }\end{array}$ & $3.66(0.89)$ \\
\hline $\begin{array}{l}\text { Organizational importance for } \\
\text { professional development }\end{array}$ & $3.71(0.92)$ \\
\hline A supportive environment & $3.91(0.86)$ \\
\hline $\begin{array}{l}\text { Human resources, such as the } \\
\text { availability of qualified staff }\end{array}$ & $3.84(0.92)$ \\
\hline $\begin{array}{l}\text { Organized groups, such as } \\
\text { unions, granting agencies, media }\end{array}$ & $2.98(1.02)$ \\
\hline
\end{tabular}

In respect to the ends to which practitioners reported having used RBI, there is a split in their reports on the instrumental use of RBI. Improving professional practices was most frequently reported whereas resolving issues in everyday practice was the least. However, the dispersion of scores on this scale was fairly small. Although mean scores of the observed factor variables gravitate around the point of neutrality, between-factor and within-factor variations in mean scores should be noted. For instance, items relating to research appraisal skills were uniformly rated high. Among these skills, online search skills and the ability to read and understand research were the most needed. On the contrary, the respondents were most reserved in their opinions about RBI. Their neutrality is noticeable for the following two items: "research is easy to understand" and "research is easy to transfer to one's practice." Considerable disparity in mean scores was observed for the variables pertaining to practice constraints where availability of time to read and apply research ranked as the most influential and the impact of organized groups (such as unions) on practitioners' decision to implement research ranked the least.

Correlation analysis examined the association between the subscales of the questionnaire and demographic variables. Because the use scores were low and not highly variable, the following composite scores were calculated:

a) use of the sources of research-based information,

b) conceptual use,

c) instrumental use, and

d) symbolic use (Root item was used for symbolic use).

Factor scores represented the four factor subscales including:

a) practitioners' opinions about RBI, 
b) awareness activities,

c) expertise, and

d) organizational factors.

Summarized in Table 3, the coefficients show that variables of job responsibility, coursework in research methods, and participation in research projects positively and significantly correlated with the four composites of self-reported use of research-based information. So did the three factors but not the organizational factors.

Table 3

\section{Correlations Between QURBI and Demographic Variables}

\begin{tabular}{|c|c|c|c|c|c|c|c|c|c|c|c|c|c|c|c|c|}
\hline & 1 & 2 & 3 & 4 & 5 & 6 & 7 & 8 & 9 & 10 & 11 & 12 & 13 & 14 & 15 & 16 \\
\hline \multicolumn{17}{|l|}{$\begin{array}{l}\text { 1. Use of RBI } \\
\text { sources }\end{array}$} \\
\hline $\begin{array}{l}\text { 2. Conceptual } \\
\text { use }\end{array}$ & $\begin{array}{c}0.66 * \\
* *\end{array}$ & & & & & & & & & & & & & & & \\
\hline $\begin{array}{l}\text { 3. Instrumental } \\
\text { use }\end{array}$ & $\begin{array}{c}0.68 * \\
* *\end{array}$ & $\begin{array}{c}0.83 * \\
* *\end{array}$ & & & & & & & & & & & & & & \\
\hline 4. Symbolic use & $\begin{array}{c}0.53 * \\
* *\end{array}$ & $\begin{array}{c}0.71 * \\
* *\end{array}$ & $\begin{array}{c}0.71 * \\
* *\end{array}$ & & & & & & & & & & & & & \\
\hline 5. Gender & 0.04 & 0.05 & 0.05 & 0.06 & & & & & & & & & & & & \\
\hline 6. Experience & -0.01 & 0.05 & -0.05 & 0.01 & $\begin{array}{c}-.010 * \\
*\end{array}$ & & & & & & & & & & & \\
\hline 7. Responsibility & $\begin{array}{c}0.15 * \\
*\end{array}$ & $\begin{array}{c}0.16 * \\
* *\end{array}$ & $\begin{array}{c}0.13 * \\
* *\end{array}$ & $\begin{array}{c}0.14 * \\
* *\end{array}$ & $-0.11 *$ & $\begin{array}{r}0.13 \\
* *\end{array}$ & & & & & & & & & & \\
\hline 8. Coursework & $\begin{array}{c}0.21 * \\
*\end{array}$ & $\begin{array}{c}0.21 * \\
*\end{array}$ & $\begin{array}{c}0.17 * \\
*\end{array}$ & $\begin{array}{c}0.19 * \\
*\end{array}$ & 0.00 & -0.04 & 0.08 & & & & & & & & & \\
\hline $\begin{array}{l}\text { 9. Participation } \\
\text { in research }\end{array}$ & $\begin{array}{c}0.32 * \\
* *\end{array}$ & $\begin{array}{c}0.34 * \\
* *\end{array}$ & $\begin{array}{c}0.30 * \\
* *\end{array}$ & $\begin{array}{c}0.26 * \\
* *\end{array}$ & -0.02 & $\begin{array}{r}0.14 \\
* *\end{array}$ & $\begin{array}{c}0.14 * \\
*\end{array}$ & $\begin{array}{c}0.30 * \\
* *\end{array}$ & & & & & & & & \\
\hline 10. Grade & -0.03 & -0.04 & -0.10 & $\begin{array}{c}-0.10 \\
*\end{array}$ & $\begin{array}{c}-0.24 * \\
* *\end{array}$ & 0.03 & 0.06 & 0.03 & 0.05 & & & & & & & \\
\hline 11. School size & 0.04 & 0.02 & 0.01 & 0.04 & $\begin{array}{c}-0.11 * \\
*\end{array}$ & 0.03 & 0.00 & 0.00 & 0.03 & $\begin{array}{c}0.33 * \\
* *\end{array}$ & & & & & & \\
\hline $\begin{array}{l}\text { 12. School } \\
\text { location }\end{array}$ & 0.06 & 0.05 & 0.03 & 0.04 & -0.05 & 0.01 & -0.11 & 0.00 & $\begin{array}{c}0.10 * \\
*\end{array}$ & -0.01 & $\begin{array}{c}0.25 * \\
* *\end{array}$ & & & & & \\
\hline $\begin{array}{l}\text { 13. Language of } \\
\text { teaching }\end{array}$ & -.004 & 0.01 & 0.05 & 0.03 & 0.07 & 0.02 & $\begin{array}{c}-0.09 \\
*\end{array}$ & -0.01 & 0.00 & $\begin{array}{c}-0.09 \\
*\end{array}$ & 0.05 & 0.06 & & & & \\
\hline $\begin{array}{l}\text { 14. Opinions } \\
\text { about RBI }\end{array}$ & $\begin{array}{c}0.35 * \\
* *\end{array}$ & $\begin{array}{c}0.43 * \\
* *\end{array}$ & $\begin{array}{c}0.46 * \\
* *\end{array}$ & $\begin{array}{c}0.37 * \\
* *\end{array}$ & 0.01 & 0.06 & $\begin{array}{c}0.11 * \\
*\end{array}$ & 0.07 & $\begin{array}{c}0.20 * \\
* *\end{array}$ & -0.04 & 0.00 & 0.04 & 0.01 & & & \\
\hline $\begin{array}{l}\text { 15. Awareness } \\
\text { activities }\end{array}$ & $\begin{array}{c}0.20 * \\
*\end{array}$ & $\begin{array}{c}0.26 * \\
*\end{array}$ & $\begin{array}{c}0.22 * \\
*\end{array}$ & $\begin{array}{c}0.19 * \\
*\end{array}$ & 0.05 & 0.00 & $\begin{array}{c}0.19 * \\
*\end{array}$ & 0.02 & $\begin{array}{c}0.13 * \\
*\end{array}$ & -0.05 & -0.02 & 0.04 & -0.02 & 0.00 & & \\
\hline 16. Expertise & $\begin{array}{c}0.16^{*} \\
*\end{array}$ & $\begin{array}{c}0.17 * \\
* *\end{array}$ & $\begin{array}{c}0.13 * \\
*\end{array}$ & $\begin{array}{c}0.15 * \\
*\end{array}$ & 0.04 & 0.02 & 0.04 & $\begin{array}{c}0.15 * \\
*\end{array}$ & $\begin{array}{c}0.16 * \\
*\end{array}$ & 0.00 & -0.04 & 0.03 & -0.02 & 0.00 & $\begin{array}{r}0.0 \\
0\end{array}$ & \\
\hline $\begin{array}{l}17 . \\
\text { Organizational } \\
\text { factors }\end{array}$ & 0.02 & 0.01 & 0.01 & 0.05 & 0.00 & 0.07 & -0.01 & -0.04 & -0.02 & -0.03 & 0.00 & -0.14 & 0.01 & 0.00 & $\begin{array}{r}0.0 \\
0\end{array}$ & $\begin{array}{r}0.0 \\
0\end{array}$ \\
\hline
\end{tabular}

$* * \mathrm{p}<.01, * * * \mathrm{p}<.001$ 
Gender and educational experience as well as all school properties, did not correlate with any of them. Administrators tend to report more involvement in research projects and give higher opinions about research and the importance of awareness activities for their practice than teachers and professionals do. Practitioners who took coursework in research methods reported higher participation in research projects as well as giving more weight to research-related skills. Prior participation in research is also positively related to practitioners' opinions about research-based information, activities to raise their awareness of research findings, and the importance they give to research-related skills for their practice.

\section{QURBI Open-ended Questions}

The thoughts shared by practitioners through the six open-ended questions represent an important part of this study's data collection. Although many respondents skipped the open-ended questions, nonetheless 504 practitioners commented in some form on at least one of them. The number of comments ranged from 362 (list sources of RBI) to 114 (dimensions of use), with the average being 208 comments per question. The majority of commenters $(84.1 \%)$ were teachers. It appeared that twice or sometimes three times more comments came from the respondents who reported having used RBI three times or more over the past year. However, we failed to find any significant relationship between the categories that emerged from the comments and frequency of self-reported use, implying that the pattern of individual preferences is likely to be independent of the self-reported behaviour of use of RBI.

In their comments about the sources of research-based information, the majority of 362 respondents $(91.7 \%)$ reported having used RBI from a blend of sources. According to them, it is challenging to choose the source truly based on the research findings as some sources lack a research base. For instance, referring to professional development workshops "resource teachers ...do not back up the methods with research. The approach turns out to be 'evangelical', i.e., supporting the latest fad with a lot of fervour, rather than presenting new ideas that are research-based." Collegial exchanges were viewed as a primary conduit of information: "I believe that a teacher is more likely to implement a new practice if it comes from a colleague who has tried it." The respondents rated colleagues the top reference source (55.8\%). The preference given to such a casual information flow contrasted with the relatively little importance attached to centralized, formal communication provided by the federal and provincial governments $(12.7 \%)$, professional unions and associations $(6.63 \%)$, and school boards (10.5\%). Respondents reported using books (48\%) more than academic journals (11.1\%). In particular, Diller's writing on literacy workstations, Caulkin's works on primary writing, and van de Walle's student-centred mathematics were referred to frequently. Internet was emphasized as an increasingly popular point of access to research findings by the respondents $(35.1 \%)$. Only $3.6 \%$ participants reported having used assessment results or information from university programs. Only $0.8 \%$ consulted research databases.

Although only 114 practitioners' out of 362 commented on "dimensions of use," $76.3 \%$ of them reported having used research findings instrumentally. This use targeted students and classrooms, school and professional communities, parents and teachers themselves. Practitioners used RBI as a classroom tool for tasks that included helping special needs students, classroom management, increasing student motivation, evaluating student performance, and empowering students in their learning. Conceptual use was reported by $35.9 \%$ mainly as a way to support 
practitioners in setting goals and developing expectations as well as to reflect, make decisions, develop a personal philosophy of teaching, and validate their practice. Reports of symbolic use of research to legitimize actions without necessarily changing practices or taking action were few (4.4\%). They pertained to justifying assessment results and curricular decisions as well as persuading parents about a particular course of action taken.

The opinions $(\mathrm{N}=256)$ that emerged about RBI were quite critical of the information itself, with criticisms targeting the irrelevance of the research (38.7\%). Research was characterized as "Ivory Tower" conducted for "perfect students with no problems, no personal issues" and "never factoring in the different environments, cultures, and socio-economic conditions kids come from." Some respondents complained that the spectrum of RBI is too broad, making it impossible to relate it consistently to classroom situations. Others judged RBI as "narrowly focused" and ignoring "possible or combined reasons for the results." The disconnect between research and practice was accounted for by a number of reasons. Specifically, researchers were described as those who never taught or did it so long ago that "they lost touch with the realities of the classroom" whereas research findings as those that often did not relate to the classroom reality, "the big ideas from the ministry." Furthermore, respondents commented that too much research was driven by U.S. trends, "extrapolating American findings on Canadian practices." A few respondents suggested that teachers' involvement in research would ensure its relevance; for instance, "partnerships involving practitioners in practical research should be favoured."

The methodological quality of educational research was also criticised, including its lack of rigour and unreliable findings. Additionally, reader "unfriendliness" of the research reports (16.8\%) "overburdened with catch phrases and keywords that hide the true impact" and a lack of their accessibility for "for quick reading," were another points of criticism. The respondents would need short and clear reports incorporating "actual examples" as well as summaries and syntheses with "a ballpark figure to gauge effectiveness." Also clear, strategic, and comprehensive recommendations should be provided to guide practice. Some reported that a limited ability to understand research, especially statistical data, might account not only for the negative perception of RBI, but also for poor utilization and misuse of the information. Practitioners suggested that pre-service and in-service education should be venues to develop the skills to read, interpret, and relate research results to teaching practice.

The physical inaccessibility of research data also discourages practitioners from using it in their practice $(12.9 \%)$. Many practitioners do not have access to online libraries and databases. Those who have access reported having some contact with universities, being university students, or maintaining contact through their previous jobs. Practitioners living in remote communities do not have adequate access. Some practitioners must rely on "hard copies of the out-dated research papers distributed at school and school board" as their only sources of RBI. In this respect, timeliness of research are also a concern.

Few respondents (7\%) produced balanced appraisals of RBI. For instance, RBI is described as "sometimes far-fetched, sometimes relevant and credible." According to them, practitioners' opinions about RBI "depend upon the research and who did it."

Even if RBI is accessed, read, understood, and found relevant, there are a number of practical challenges to its systematic use in the classroom (12.5\%). Lack of support and resources, large classes, lack of time to plan for changes and to modify the information to meet students' needs, and the mere stress of the day "often cause practitioners to lapse into a more 
traditional pedagogical method because it offers the path of least resistance, not because it is best practice."

Comments on "activities raising awareness" of research findings $(\mathrm{N}=192)$ emphasized the importance of demonstrating how the findings of a particular study can be used in classroom practice $(26.7 \%)$. To be useful, these demonstrations should reflect classroom reality and show how findings can be incorporated into practice seamlessly. Practitioners reported they would also appreciate lesson plans and assessment tools based on research findings. These plans and tools could be incorporated into workshops and seminars delivered in person or as video clips via the Internet. For instance, $20 \%$ of the respondents suggested an open-access meta-resource, "access point," "tool box," "resource bank," or "central list of research," consolidating summarized or synthesized applied educational research. As a longed-for tool to improve school practice, this resource would be accompanied by clear recommendations and demonstrations and structured by subject or problem areas.

Comments on expertise needed to use RBI $(\mathrm{N}=143)$ ranged from skills and individual dispositions to external support and expertise. A key set of abilities included information search skills $(9.6 \%)$, research appraisal skills $(20.6 \%)$, expertise to relate and adapt research results to practical context $(20.6 \%)$, abilities to summarize and communicate available research findings (6.2\%), and abilities to conduct one's own research (6.2\%). The importance of external support was mentioned by $27 \%$ of respondents. They need the presence of a "more knowledgeable other" (expert) who can work well with teachers and other practitioners to discuss and explain research, to summarize and translate ideas that are relevant to teachers, to demonstrate the usefulness of findings in a classroom setting, and to provide tools and resources to help apply RBI in a particular situation.

Among the reported "organizational factors" $(\mathrm{N}=177)$, lack of time was an important barrier to practitioners' decision to use RBI (26.4\%). Time is needed to search out sources and then read, understand, reflect, and incorporate ideas into practice. Some suggest that such time should be formally allocated in job contracts or assigned by school administrations or school boards. Others propose time-saving strategies and demand ready-made materials: "Just provide the data and the appropriate lesson plan, and I am in." Others feel that the using research is part of their obligation to students: "I can't wait until the powers decide when it will be the time. Nor can I use the excuse of time, or other reasons not to explore my teaching."

Support and encouragement were reported as another critical need (52\%). School practitioners count mainly on school administrations for support $(27.7 \%)$ as they "can allow time," "encourage team meetings," and "promote a safe working environment for research inquiry." However, the use of RBI should become a priority for school leaders: "Emphasis and priority on research-based information need to start with school administration to effectively filter down to teachers." There is possibly only a fine line separating engaging and encouraging initiatives from authoritative force and pressure. As a result, some practitioners develop resistance to the top-down approach: "Research that I am told to use makes me resist . . . I use research when I feel it will be useful to me, not when someone else pressures me."

As well, proactive leadership needs to be combined with the effort of the school community to contribute to a spirit of research-based school practices. Respondents mentioned a "critical mass of people" who could unite colleagues doing research or who are involved in successful implementation of research findings (13\%); support from school boards (11.3\%), professional unions and governments (10.7\%), and parental support (3.9\%). 
A number of respondents (12.4\%) also mentioned that political and ideological agendas pursued by governing bodies at various levels do not usually take proper account of RBI. Some reported conflicts that emerged when educational groups and organizations pushed information based on their priorities, and ignored or hampered practitioners' initiatives to use research findings relevant to their teaching practice. It is even more complicated when the expectations and requirements of ministries and boards clash; practitioners strongly oppose getting involved in such a "battle of dueling experts."

\section{Discussion}

The data collected in this online survey shows that use of RBI by individual practitioners continues to be a challenge. In accordance with previous findings (Bérubé, 2005; Kretlow \& Helf, 2013; Williams \& Coles, 2007; Lysenko et al., 2014), practitioners' self-reports are marked by low-threshold use. Despite this infrequent use, our data did reveal a pattern of sources used, hinting at the nature of information favoured by school practitioners. When compared with previous findings (e.g., Williams \& Coles, 2007), the number of practitioners who use the World Wide Web for sources has increased, with practitioners commenting on the Web's ability to give relatively unrestricted access to information. Also remarkable is the importance given to peer exchanges of practice-relevant information, with the open-ended reports implying that colleagues (both near and far) are a primary source of information.

However, Internet sources and collegial networking may not always have a foundation in research findings. For instance, despite the fact that a number of practitioners referred to governmental, professional, and school board Web sites and electronic databases as their major sources, others reported their reliance on blogs, general search tools like Google and Yahoo, and social media platforms. Schneider's (2008) qualitative study of "edubloggers" online training practices suggests that rarely did these bloggers validate their content, indicate references, or even take any training courses. While collegial networking can bring research to the front lines of educational practice quite quickly, the quality of the "word of mouth" stratagem should not be over-estimated either. Davis (2008) argues that these accounts of research are often truncated, decontextualized, and blended with anecdotal experiences of the colleague, rendering them largely inaccurate.

Contrary to the argument that practitioners are more prone to use local data, which they value for its contextual relevance as opposed to the research generated in academia, the self-reports revealed low use of school evaluation data. Only $6 \%$ of commenters mentioned that assessment data informed their teaching. Whether the data are accessible or usable for making individual or collective decisions is unknown. However, the comments suggest that these contextually relevant data do not often trickle down to the interested teachers.

It is important to note that respondents rarely referred to teacher education programs as a source of RBI. According to Cousins and Walker (2000), only novice practitioners refer to teacher education programs to compensate for their lack of experience. In our sample, only $17 \%$ of respondents had less than three years of experience, and there was no observable relationship found between teaching experience and the use of RBI. Consistent with the literature (e.g., Cousins \& Walker, 2000), coursework in research practice as well as prior participation in research projects were associated with the self-reported use of research-based information. On the one hand, this link implies that the effects of formal training in which research practice is 
incorporated are likely to stay with practitioners. On the other hand, research experience gained in their workplace through participation in research projects may also increase teachers' engagement with RBI.

In terms of how practitioners use RBI, the self-reports suggest predominantly instrumental uses. However, respondents would rather use RBI for the broader purpose of improving professional practices than for finding solutions to everyday issues. It is possible that the research findings aren't presented in a way that offers answers to specific issues of practical concern or perhaps practitioners are simply used to going elsewhere (e.g., to colleagues) to find a quick fix.

Although existing studies report that educational practitioners express positive attitudes towards educational research (e.g., Ratcliff et al., 2005; Williams \& Coles, 2007), the respondents in this study took a neutral stance and we can only speculate about the reasons for their position. Research knowledge utilization has become a buzzword in education and practitioners might feel obliged to hide their negativity about the value of educational research to conform to the prevailing winds. This supposition receives support from the negative comments made about RBI, namely that research isn't rooted in school reality, is often irrelevant, is difficult to access, and contains convoluted language. The fact that these comments were given by the respondents who reported having used research should raise the red flag to communities engaged in research production and dissemination, including universities and research-brokering organizations inside and outside the school system.

Both the qualitative and quantitative data reveal the importance practitioners attribute to the potential of research to improve practice. They gave clear and explicit requests for research publications to offer more specific recommendations for applying research findings to practice. Practitioners valued professional development activities as a way to raise awareness of RBI. They suggested information literacy skills together with the ability to appraise and act upon research evidence combined with a willingness and openness to change as being critical for the use of research to inform classroom practice. At the same time, the availability and accessibility of external expertise to help with basic understanding of research and its adaptation and application was also valued. Practitioners noted the importance of structural support, especially time and collaboration, in the successful use of research knowledge. Time especially was identified as essential for searching out sources, reflecting on the material, and incorporating ideas into practice.

\section{Conclusions}

Although the selected research methodology has limitations such as correlational design, self-reports, and non-probabilistic sampling, several lessons can be gleaned from this study, particularly about the need to cultivate positive attitudes toward and capacity of research use. Firstly, teacher education programs can help practitioners develop a solid foundation in the skills needed to engage in and with research by formulating questions, finding solutions by searching for and appraising existing information for appropriateness, applying the information, and evaluating its effectiveness. Teacher programs should balance courses in curriculum and instruction with systematic inquiry activities and classes that emphasize the practical value of evidence generated from research. Ideally, professors should communicate an interest in pedagogical and education research to underscore the importance of such research in informing 
classroom practice. Secondly, a more systemic approach is needed to ensure that using research-based information is not abandoned once novice practitioners enter the school system. Research-based information should be readily accessible to busy practitioners and decision makers. There needs to be a "place," a public resource where such information can be brought together, assessed for quality and relevance, and then organized for professional use. Effective models for condensing research-based information and communicating it to educational professionals can be found in the health and social care fields. Similarly, expansion of research brokering organizations as intermediaries between educational research and practice may stimulate research use by their capacity-building functions, implementation support, organizational development, and policy influence (Cooper, 2014). Finally, there need to be structures in place to support the practitioner. These structures should: (a) provide access to research that is written for non-scientists and accompanied by clear recommendations and demonstrations on how it is to be effectively applied, (b) integrate on-going research-based professional development, (c) create opportunities and stimulating intellectual needs to share experience gained in research implementation, and (d) put in place administrative and managerial support structures for the time and energy required.

In sum, this research suggests that there is a way to go to ensure that knowledge generated by educational research routinely informs educational practice. Systemic and coordinated efforts by those on both research and practice sides-including school boards, education faculties, and knowledge mobilization agents - are required to build the school capacity structure and enable teachers to be key innovation agents whose teaching makes a difference at the end of the day. 


\section{Acknowledgements}

This work was supported by a Social Sciences and Humanities Research Council of Canada Presidential Fund (Grant \# S 012115). 


\section{References}

Bérubé, B. (2005). L'accès à la recherche en enseignement et son utilisation dans la pratique : résultats d'une enquête auprès des enseignants et des enseignantes du préscolaire, du primaire et du secondaire. [Access to educational research and its use in educational practice: The survey results of teachers in kindergarten, elementary and secondary schools]. Retrieved from Conseil supérieur de l'éducation website: http://www.cse.gouv.qc.ca/EN/Download/index.html?id= 50-2099en\&cat=50-2099_EN

Coburn, C. E., Honig, M. I., \& Stein, M. K. (2009). What's the evidence on districts' use of evidence? In J. D. Bransford, D. J. Stipek, N. J. Vye, L. M. Gomez \& D. Lam (Eds.), The role of research in educational improvement (pp. 67-87). Cambridge, MA: Harvard Education Press.

Cooper, A. (2014). Knowledge mobilization in education across Canada: A cross-case analysis of 44 research-brokering organizations. Evidence \& Policy, 1, 29-59. http://dx.doi.org: /10.1332/174426413X662806

Cousins, J. B., \& Walker, C. (2000). Predictors of educators' valuing of systematic inquiry in schools. Canadian Journal of Program Evaluation, Special Edition, 25-52.

Dagenais, C., Janosz, M., Abrami, P. C., Bernard, R. M., \& Lysenko, L. (2008). Integrating research-based information into professional practices by teachers and administrators: Towards a knowledge transfer model adapted to the education environment: Executive Summary. Retrieved from http://www.ccl-cca.ca/pdfs/FundedResearch/Dagenais-ExecSumm-E-SL2006.pdf

Dagenais, C., Lysenko, L., Abrami, P., Bernard, R., Ramde, J. \& Janosz, M. (2012). Use of research-based information by school practitioners and determinants of use: A review of empirical evidence, Evidence and Policy, 8, 285-309.

Davis, S. H. (2008). Research and practice in education: The search for common ground. Lanham, MD: Rowman \& Littlefield Education.

Estabrooks, C.A. (1999) Modeling the individual determinants of research utilization. Western Journal of Nursing Research, 21, 758-772. doi:10.1177/01939459922044171

Hughes, M., McNeish, D., Newman, T., Roberts, H., \& Sachdev, D. (2000). What works? Making connections: Linking research and practice. Essex, U.K. Barnardo's.

Knott, J., \& Wildavsky, A. (1980). If dissemination is the solution, what is the problem? Knowledge: Creation, Diffusion, Utilization, 1, 537-578.

Kretlow, A. G., \& Helf, S. S. (2013). Teacher implementation of evidence-based practices in Tier 1: A national survey. Teacher Education and Special Education, 36, 167-185.

Leech, N. L., \& Onwuegbuzie, A. J. (2011). Beyond constant comparison qualitative data analysis: Using Nvivo. School Psychology Quarterly, 26, 70-84. doi:10.1037/a0022711

Levin, B. (2013). To know is not enough: research knowledge and its use, Review of Education, 1, 2-31. doi:10.1177/0888406413489838 
Lysenko, L., Abrami, P., Bernard, R., Dagenais, C., \& Janosz, M. (2014). Educational research in educational practice: Predictors of use. Canadian Journal of Education. 37(2). Retrieved from http://www.cje-rce.ca/index.php/cje-rce/article/view/1477

Neilson, S. (2001). Knowledge utilization and public policy processes: A literature review. IDRC-Supported Research and its Influence on Public Policy. Retrieved from http://idrinfo.idrc.ca/archive/corpdocs/117145/litreview_e.html

Organization for Economic Co-operation and Development. (2007). Knowledge management: Evidence and education. Linking research and practice. Paris, France: OECD Publications Service.

Organization for Economic Co-operation and Development. (2010). Evidence in education: Linking research and policy. Paris, France: OECD Publications Service.

Ratcliffe, M., Bartholomew, H., Hames, V., Hind, A., Leach, J., Millar, R. \& Osborne, J. (2005). Evidence-based practice in science education: the researcher-user interface. Research Papers in Education. 20, 169-186. http://dx.doi.org/10.1080/02671520500078036

Rogers, E.M. (2003). Diffusion of Innovations ( $5^{\text {th }}$ ed). New York: Simon and Schuster.

Schneider, K. (2008). A qualitative study of five authors of five blogs on training and development. Unpublished MA dissertation. Concordia University, Montreal, Canada. Retrieved from http://spectrum.library.concordia.ca/975987/1/MR45326.pdf

Sharples, J. (2013). Evidence for the Frontline. Retrieved from Alliance for Useful Evidence website:http://www.alliance4usefulevidence.org/assets/EVIDENCE-FOR-THEFRONTLINE-FINAL-5-June-2013.pdf.

Sunesson, S., \& Nilsson, K. (1988). Explaining research utilization beyond "functions". Knowledge: Creation, Diffusion, Utilization, 10, 140-155.

Walter, I., Nutley, S.M., \& Davies, H.T.O. (2005). What works to promote evidence-based practice? A cross-sector review. Evidence \& Policy, 1, 335-364.

Weiss, C.H. (1980). Knowledge creep and decision accretion. Knowledge: Creation, Diffusion, Utilization, 1, 381-404.

Williams, D. \& Coles, L. (2007). Teachers' approaches to finding and using research evidence: an information literacy perspective. Educational Research, 49, 185-206. http://dx.doi.org/10.1080/00131880701369719 